\title{
Utilizing Spirogyra grevilleana as a Phytoremediatory Agent for Reduction of Limnetic Nutrients and Escherichia coli Concentrations
}

\author{
Malcolm A. Barnard1, James W. Porter ${ }^{1}$, Susan B. Wilde ${ }^{2}$ \\ ${ }^{1}$ Eugene P. Odum School of Ecology, University of Georgia, Athens, GA, USA \\ ${ }^{2}$ Daniel B. Warnell School of Forestry and Natural Resources, University of Georgia, Athens, GA, USA \\ Email: ^Malcolm.barnard@uga.edu
}

How to cite this paper: Barnard, M.A., Porter, J.W. and Wilde, S.B. (2017) Utilizing Spirogyra grevilleana as a Phytoremediatory Agent for Reduction of Limnetic Nutrients and Escherichia coli Concentrations. American Journal of Plant Sciences, 8, 1148-1158.

https://doi.org/10.4236/ajps.2017.85075

Received: April 8, 2017

Accepted: April 27, 2017

Published: April 30, 2017

Copyright $\odot 2017$ by authors and Scientific Research Publishing Inc. This work is licensed under the Creative Commons Attribution International License (CC BY 4.0).

http://creativecommons.org/licenses/by/4.0/

\begin{abstract}
The freshwater alga Spirogyra grevilleana was used in an experimental biofiltration system to reduce levels of Escherichia coli, nitrates, and phosphates. Water collected from a 2.32 ha lake in Atlanta, Georgia, USA was pumped at a constant rate $\left(6.17 \times 10^{-1} \mathrm{~m}^{3} \cdot \mathrm{hr}^{-1}\right)$ through the algal filtration devices with low and high concentrations of $S$. grevilleana. Effluent water was tested over time for E. coli, nitrate, phosphate, dissolved oxygen, and $\mathrm{pH}$ levels. Both concentrations of $S$. grevilleana reduced $E$. coli by $100 \%$ and significantly reduced nitrate concentrations $(30 \% \pm 13 \%)$ and phosphate concentrations $(23 \% \pm 5 \%)$ while maintaining dissolved oxygen and $\mathrm{pH}$ at normal levels. Utilizing $S$. grevilleana in an algal filtration device could potentially provide a sustainable, flexible, and low-cost method of $E$. coli reduction in freshwater lakes worldwide. Initial results indicate that the use of $S$. grevilleana in conjunction with an algal filtration device is potentially capable of creating potable water.
\end{abstract}

\section{Keywords}

Spirogyra grevilleana, Bioremediation, Phytoremediation, Nutrients, Escherichia coli

\section{Introduction}

Freshwater ecosystems have been critical to sustain life and establish civilizations throughout history. Human settlements worldwide concentrated near freshwater ecosystems, with "over half the world's populations [living] within $20 \mathrm{~km}$ of a permanent river" [1]. One of the most widespread global issues of the $21^{\text {st }}$ Cen- 
tury is scarcity of clean water. As human populations grow, increased agricultural and industrial production, combined with poor sanitation practices, has led to a widespread increase in water pollution. Biological contaminants, such as Escherichia coli (E. coli), are contaminating most freshwater lakes [2].

This study focuses on the filamentous green alga, Spirogyra grevilleana, as a potential biofilter capable of decreasing of $E$. coli concentrations as well as nutrients levels in freshwater lakes. Potential positive effects of algae on water quality have been established through prior experimentation and research [3] [4]. This study demonstrates that the use of $S$. grevilleana in a novel filtration device can improve water quality relating to concentrations of $E$. coli, nitrates, and phosphates, while at the same maintaining desired dissolved oxygen and $\mathrm{pH}$ levels. If successfully scaled up, this device could be used in freshwater lakes to decrease the negative effects of $E$. coli as well as nutrient pollution and subsequent eutrophication. Spirogyra is commonly found in freshwater, and will proliferate and form dense mats in lakes and reservoirs with high nutrient levels [5].

Algae produce a variety of secondary metabolites including carotenoids, phenolic compounds, phycobiliprotein pigments, polysaccharides, and unsaturated fatty acids [5]. These natural products can have antioxidant, anticancer, antimicrobial, antibacterial, antiviral, antialgal, and antifungal properties, as well as bioremediation potential [6]. Antimicrobial activity against a multitude of bacteria and fungi has been documented in Spirogyra [7]. Extracts from Spirogyra spp. contain n-butanol, which has been shown to retard growth of both grampositive and gram-negative bacteria [8]. Many early civilizations, including those in ancient Egypt, used natural compounds extracted from samples of Spirogyra $s p p$. as primitive antibiotics [9]. Spirogyra spp. reduces bacterial levels of E. coli and other aquatic bacteria (such as Giardia spp.), not only by reducing the nutrient levels needed to sustain bacterial populations, but also by secreting antibacterial compounds into the water [10]. Spirogyra spp. is easily grown in culture and available for global distribution [11].

According to Rosen, Croft [12], the 1994 National Water Quality Inventory listed bacteria as the leading cause of impairment for rivers and streams. E. coli is a species of heterotrophic bacteria classified as coliform [13]. In addition to organic matter, catalysts for $E$. coli growth include high nutrients, warm temperatures, stagnant water conditions, and dense harmful algal mats [14]. E. coli is also a widely used indicator of contamination originating from domestic sewage [15]. Although E. coli is not generally pathogenic, its presence in surface water at elevated levels often indicates the presence of fecal contamination as well as co-occurring pathogens such as Salmonella, Streptococci, Cryptosporidium, Giardia, and Enterovirus [16]. Contaminated surface water facilitates direct human exposure to waterborne pathogens [17].

Excess nutrients, primarily nitrogen and phosphorous from fertilizers, stimulate algae productivity, including filamentous green algae, and contribute to harmful algae blooms [18] Excessive algal blooms and aquatic weed infestations can intensify vertical stratification, hypolimnetic anoxia, and formation of car- 
cinogens during water chlorination [17]. Today, eutrophication of natural waters, caused by an increase in dissolved nutrients, is one of the most significant causes of declines in water quality [19]. Although eutrophication is a natural process of aging of lakes and water bodies, human activities can greatly accelerate eutrophication by increasing the rate at which nutrients and organic substances enter aquatic ecosystems [20]. Phosphorus has been shown to be a limiting nutrient controlling phytoplankton growth in the Great Lakes [21]. In Lake Erie, hypoxia has been directly linked to elevated in-lake total phosphorus concentrations and excessive external total phosphorus loading. State laws limited phosphates in detergents in an effort to reduce these effects. Prior to the ban, phytoplankton assemblages shifted towards dominance by taxa favored under nutrient-rich conditions, cyanobacteria, filamentous green algae (esp. Cladophora) and red algae, Bangia [21] [22]. Cladophora can harbor high levels of fecal indicator bacteria and bacterial pathogens [22]. Following the ban, loading of total phosphorus and dissolved oxygen depletion rates declined significantly, total algal biomass decreased, and there were fewer blooms of nuisance species [23]. Algae are currently utilized to improve water quality on a large scale through a device called an "Algal Turf Scrubbers." An Algal Turf Scrubber usually consists of a series of filtration troughs with thin screens to catch filamentous algae [24]. Adey, Kangas [24] defined algal turfs as "communities of organisms dominated by aggregations of unicellular to branched filamentous algae and cyanobacteria (blue-green algae)". The original use of ATS, as invented by Walter Adey, was to clean aquariums on display at the Smithsonian [24] [25]. Currently, University of Maryland researcher Patrick Kangas is applying ATS systems to improve water quality in large open-water systems (e.g. Chesapeake Bay). These systems are expensive to install and maintain, and require extensive surface area on both land and water [25]. The dimensions of an average ATS land-based system are $50 \mathrm{~m}$ by $1800 \mathrm{~m}$. Approximately 10,000 acres of land-based and floating ATS systems would be needed to significantly remove nutrients from large bodies of water the size of Chesapeake Bay [25].

Flexible, low-cost, and sustainable methods of bacterial and nutrient reduction in freshwater lakes are critically needed. The experiments described in this paper were initiated to test the efficacy of utilizing $S$. grevilleana as an algal filtration method for biologically reduction of $E$. coli, nitrate, and phosphate levels. A long-term goal of this work is to produce potable water from freshwater lakes using algal filtration devices.

\section{Materials and Methods}

An Algal Filtration Device (AFD) (Figure 1) was constructed using convex metal mesh tea filters placed on both ends inside of a removable cartridge designed to hold algae. The cartridge and experimental devices were built with transparent PVC pipe so that algae would have solar exposure for photosynthesis. The cartridge containing algae was opened on both ends and inserted into the experimental device. The device was closed and the pump turned on. Lake water was 


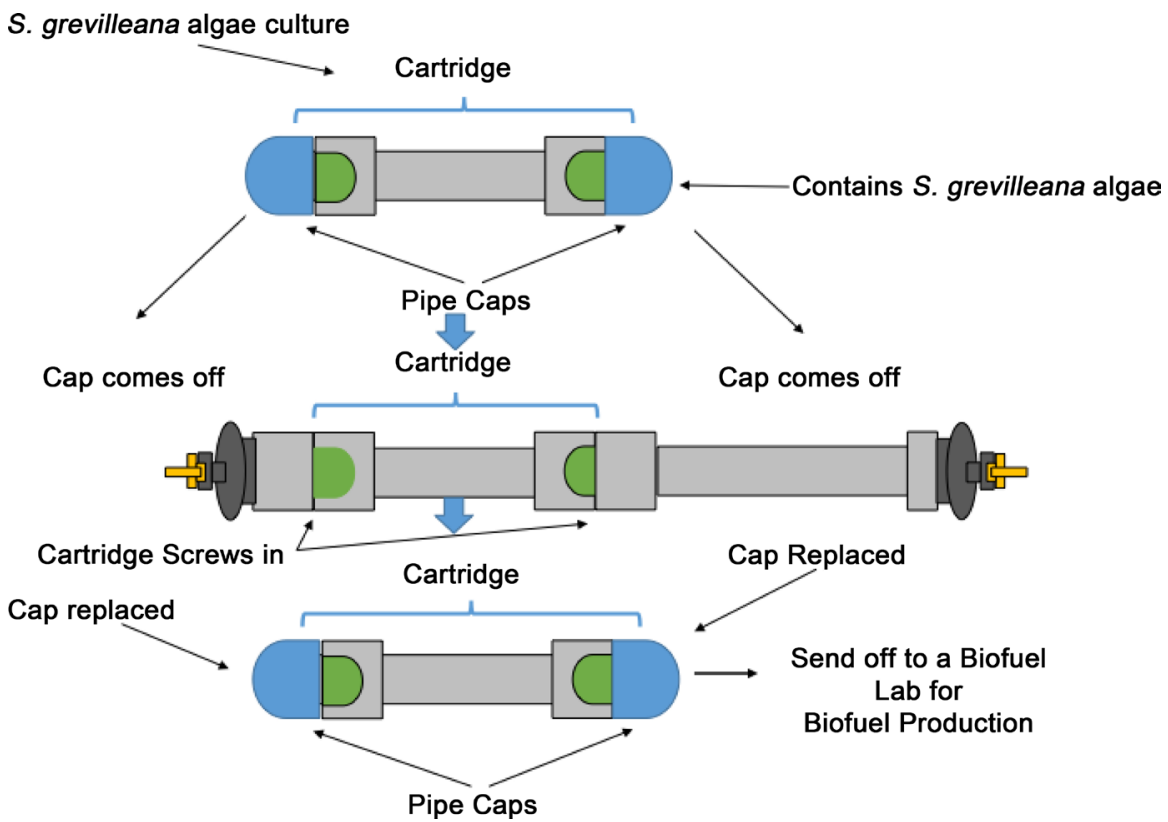

Figure 1. The Algal Filtration Device (AFD) is constructed with clear PVC pipes fitted with two ends, algal cartridge and center connector.

continuously circulated through the AFD utilizing clear plastic tubing attached to a recirculating fountain pump in the sample bucket (Figure 1).

Initially twelve prototype Algal Filtration Devices were constructed using 7.62 $\mathrm{cm}$ clear PVC pipes fitted with two ends, algal cartridge and center connector (total length $60.96 \mathrm{~cm}$ ). A cartridge with domed mesh inserts fitted inside on both pipe ends and clear connectors was constructed to screw into the AFD. Bushing and barbed fittings were added on the other end of the pipe to provide a seal between the pipe and tubing. The male and female connectors were screwed together and tubing secured on each end (Figure 1). The devices were tested for function and seal with distilled water, and then sanitized with by rinsing twice with a $10 \%$ chlorine solution.

Twelve replicate sample buckets were tested for two levels of algal biomass cartridges with $16 \mathrm{~L}$ of water collected from a St. Johns, GA Recreations Lake near Atlanta, GA $\left(33^{\circ} 59^{\prime} 29.04^{\prime \prime} \mathrm{N} ; 84^{\circ} 15^{\prime} 26.64^{\prime \prime} \mathrm{W}\right)$. Buckets were sealed, transported to the lab, and lids were removed overnight. Each sample bucket was then outfitted with a circulating pump and an algal filtration device (Figure 2).

Each of the experimental devices was unscrewed in the center of the device on the cartridge end and 10 test tubes $(15 \mathrm{ml})$ of $S$. grevilleana were added to each cartridge. For Phase 2, 30 test tubes containing $\sim 15 \mathrm{ml}$ of $S$. grevilleana culture were added to each treatment cartridge. No algae were added to the control cartridges.

The cartridges were screwed on to one end of the device, then the threads of the center connectors were covered in plumbing tape and screwed shut for a tight seal. One of the recirculating pumps was affixed to the bottom of the experimental sample bucket using suction cups on the bottom of the pump, and then connected to the closest barbed fittings on the experimental device using clear 


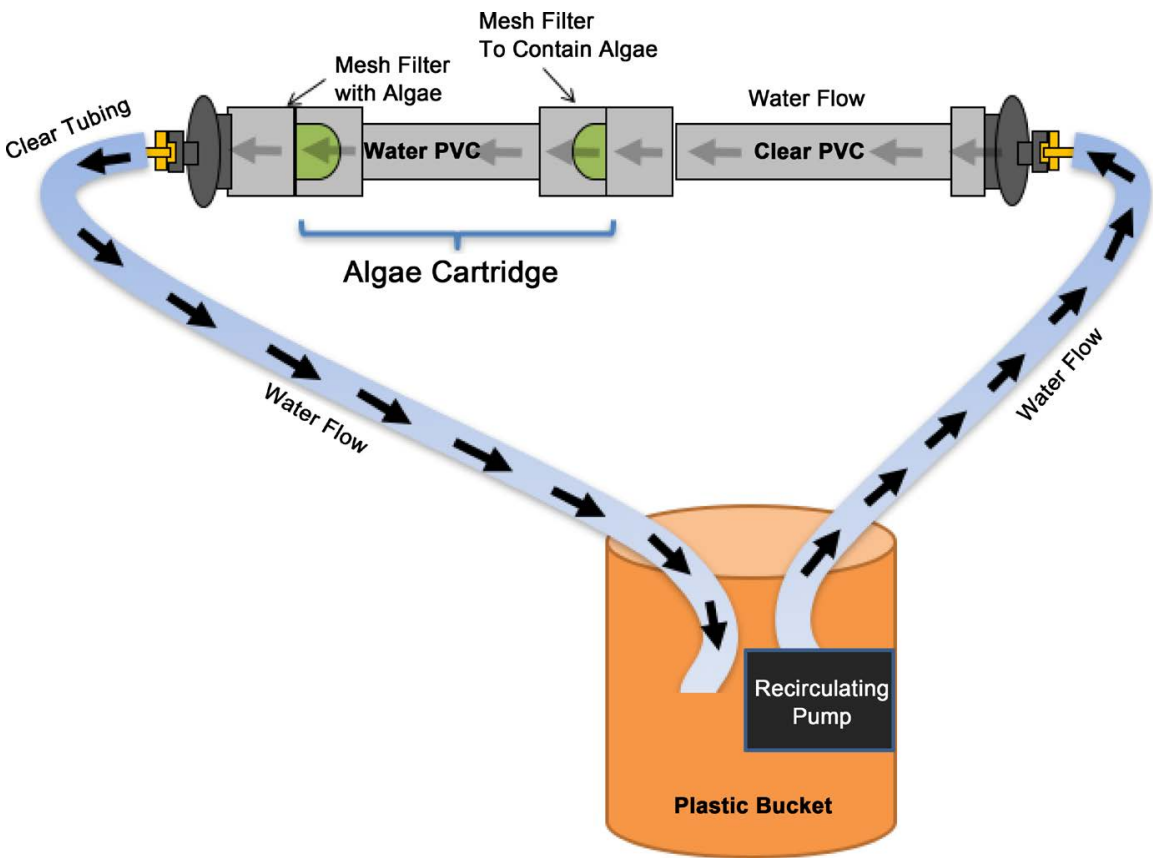

Figure 2. Each experimental bucket had recirculating pump to move water through clear tubing connected to the Algal Filtration Device (AFD) and additional tubing to return filtered water to the bucket.

rubber tubing. An additional tube was attached to the far end of the experimental device and fed back into the sample bucket. Tubing and recirculating pumps were connected for the remaining sample buckets using the same method. The pumps were plugged in and turned on for the duration of testing.

E. coli, nutrients, dissolved oxygen and $\mathrm{pH}$ were measured bi-weekly. E. coli testing was conducted using $3 \mathrm{M}$ Petrifilm $E$. coli/Coliform Count Plates [16]. Three replicate sample coliform plates were made from each sample bucket, plus a negative control plate. Using a sterile glass $2 \mathrm{~mL}$ pipette, $1 \mathrm{~mL}$ of distilled water was pipetted onto each $3 \mathrm{M} \mathrm{E}$. coli plate and plates were enumerated following a 48 hour incubation at $35^{\circ} \mathrm{C} \pm 1^{\circ} \mathrm{C}$. Nitrate and phosphate levels were read using a Hach DR890 [26]. Surface levels of dissolved oxygen were determined using the PASCO PASSPORT connected to the SPARK system. An Oakton pH Eco Tester 2 meter $\mathrm{pH}$ was used to determine surface $\mathrm{pH}$ for each sample bucket.

\section{Results and Conclusions}

This experiment utilized devices that were designed to contain $S$. grevilleana and form an algal filter for filtering lake water. All the experimental and control devices for both phases were built utilizing the same specifications. Phase 1 experimental devices contained 10 test tubes of $S$. grevilleana per device. Phase 2 experimental devices contained 30 test tubes of $S$. grevilleana per device. In Phase 1 , the algae thinly covered the mesh filter; a doubling of algal biomass was tested in Phase 2, which created a thicker algal mat that densely covered the mesh filter.

E. coli was reduced by almost $100 \%$ for experimental and control groups in both phases (Figure 3). The experimental groups in both phases had a higher 

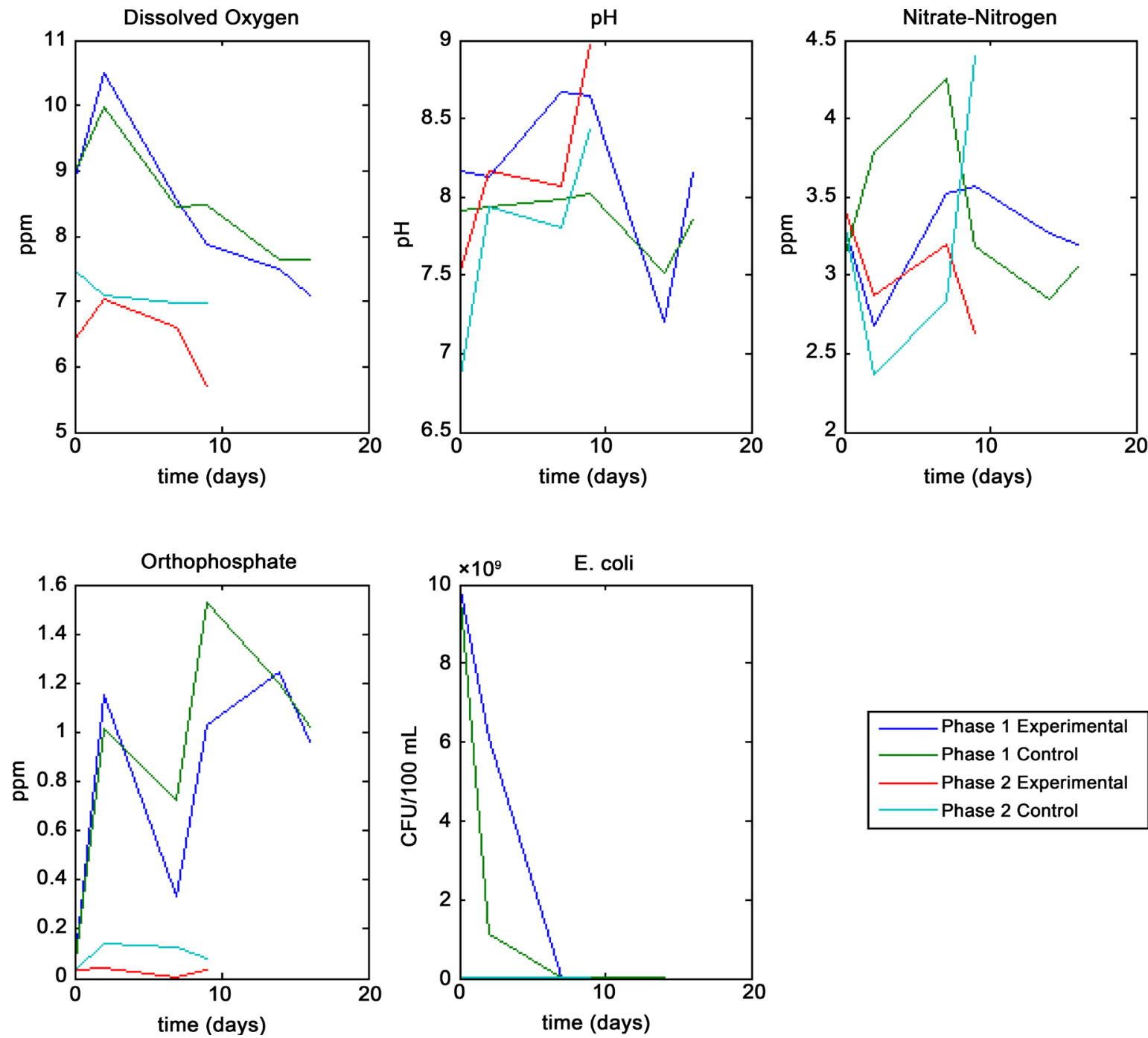

Figure 3. Changes in water quality parameters over the course of the experiment.

Table 1. Percent Change in Dissolved Oxygen, $\mathrm{pH}$, Nutrients and E. coli from initial to final reading.

\begin{tabular}{ccccc}
\hline \multirow{2}{*}{ Parameter } & \multicolumn{2}{c}{ Phase 1 } & \multicolumn{2}{c}{ Phase 2 } \\
\cline { 2 - 5 } & Experimental & Control & Experimental & Control \\
\hline Dissolved Oxygen & $-20.0 \%$ & $-14.7 \%$ & $-10.9 \%$ & $-6.7 \%$ \\
$\mathrm{pH}$ & $-0.8 \%$ & $-0.8 \%$ & $+19.6 \%$ & $+24.0 \%$ \\
Nitrates & $+23.2 \%$ & $-2.6 \%$ & $-23.3 \%$ & $+23.4 \%$ \\
Phosphates & $+13.5 \%$ & $+159.1 \%$ & $-29.8 \%$ & $+185.2 \%$ \\
E. coli & $-100 \%^{+}$ & $-100 \%^{+}$ & $-100 \%^{+}$ & $-100 \%^{+}$ \\
\hline
\end{tabular}

initial rate of $E$. coli removal than the control groups during the peak periods of $E$. coli reduction. The algal filtration device with $S$. grevilleana efficiently reduced $E$. coli levels, more rapidly than the control device until those levels were so low that efficiency rate was not measureable (Table 1 ). The increase in relative E. coli removal efficiency during Phase 2 may have been due to higher con- 
centrations of secondary metabolites produced by higher mass of $S$. grevilleana. These could result in an instantaneous, rapid reduction of $E$. coli. The relatively thin layer algal biomass utilized in Phase 1 may have required additional time to build up critical levels of secondary metabolites lethal to most E. coli.

The additional algae added to the experimental devices in Phase 2 also increased the effectiveness of the devices for removing nitrate and phosphates from the water. In Phase 1, the experimental group had nitrate levels increased by $23.2 \%$ and phosphate levels reduced by $13.5 \%$. The control group had nitrate levels reduced by $2.6 \%$ and phosphate levels increased by $159.1 \%$. In Phase 2 , the experimental sample had nitrate levels reduced by $23.3 \%$ and phosphate levels reduced by $29.8 \%$. The Phase 2 control group had nitrate levels increased by $23.4 \%$ and phosphate levels increased by $185.2 \%$.

Dissolved oxygen levels decreased in all experimental and control treatments. During Phase 1, dissolved oxygen levels decreased by $20 \%$ in treatment buckets and $14.7 \%$ in controls. Dissolved oxygen levels in Phase 2 treatment buckets decreased by $10.9 \%$ and controls decreased by $6.7 \%$. The $\mathrm{pH}$ levels decreased slightly for both the experimental and control groups in Phase $1(-0.8 \%)$ in Phase 1. During Phase 2, pH increased by $19.6 \%$ in treatment groups and $24.0 \%$ for the control group, however, dissolved oxygen $\left(6-10 \mathrm{mg} \cdot \mathrm{L}^{-1}\right)$ and $\mathrm{pH}(6-9)$ remained at safe levels throughout both trials.

This experiment successfully utilized $S$. grevilleana to reduce $E$. coli and excess nitrates and phosphates from the test water. The U.S. EPA sets safety standards for recreational use of the surface water (fishing and swimming), and potable water standards for human consumption. Surface water standards are based on thresholds of different parameters, including general water quality levels, bacterial concentrations, and nutrient levels. Potable water standards have stricter threshold values and include additional parameters (i.e. dissolved metals) relative to surface water regulations. Levels of tested parameters, E. coli, nitrates and phosphates, are critical components of surface and potable water [27].

The initial $E$. coli count overall for Phase 1 was too numerous to count (TNTC). Following algal filtration the E. coli count was reduced to EPA $E$. coli standards for surface water, and $16.7 \%$ of the samples met the EPA E. coli standards for potable water. The initial $E$. coli count for Phase 2 was also high but, following algal filtration the overall $E$. coli count met EPA E. coli standards for surface water, and $22.3 \%$ of the samples met the EPA E. coli standards for potable water. Rather than promoting $E$. coli growth, $S$. grevilleana decreased their population numbers and reduced the concentrations of nitrogen and phosphorous available for their growth. Algal reduction in bacterial levels is mediated through various metabolic processes, including the excretion of antibacterial secondary metabolites [28] [29].

According to the results from these experiments, there is strong evidence to suggest that $S$. grevilleana deployed in this algal filtration device has the potential to filter lake water to provide a source of potable water to EPA certified standards. In both Phase 1 and Phase 2, E. coli and nitrate levels were reduced to 
Table 2. Comparison of the Algal Filtration final water results to EPA potable water standards.

\begin{tabular}{cccc}
\hline \multirow{2}{*}{ Parameter } & EPA Threshold & \multicolumn{2}{c}{$\begin{array}{c}\text { This experiment } \\
\text { (averages unless stated otherwise) }\end{array}$} \\
\cline { 3 - 4 } & & Phase 1 & Phase 2 \\
\hline $\mathrm{pH}$ (Secondary Standard) & $6.5-8.5$ & 8.150 & $8.967^{+}$ \\
Nitrates (Primary Standard) & $<10 \mathrm{mg} \cdot \mathrm{L}^{-1}$ & $3.183 \mathrm{mg} \cdot \mathrm{L}^{-1}$ & $2.633 \mathrm{mg} \cdot \mathrm{L}^{-1}$ \\
E. coli/Coliform (Primary Standard) & $<5 \%$ positive plates & $0 \%{ }^{*}$ & $0 \%{ }^{*}$ \\
\hline
\end{tabular}

${ }^{+} \mathrm{High}$ but $\mathrm{pH}$ is an optional (secondary) standard; ${ }^{\star}$ Based on a three plate sample from one of the water samples.

ranges that fell within the EPA threshold range for potable water. $\mathrm{pH}$, which is an optional secondary standard for potable water, was also in range for Phase 1. In Phase 2, the $\mathrm{pH}$ falls only slightly out of range for EPA standards, but a small deviation in $\mathrm{pH}$ would not hinder potability of the water (Table 2). Further experimentation and testing of additional parameters, such as metals, would be needed prior to implementation.

The U.S. EPA posts surface water regulations to monitor bodies of water for level of recreational use. To ascertain the potential correlation of the results to EPA water standards, adherence to parameter thresholds was considered. According to EPA standards, the filtered water from both Phase 1 and Phase 2 would have been considered safe for swimming.

The algal filtration device tested in this experiment differs from currently utilized filtration devices, such as ATS technology. The algal filtration device requires only a small footprint and is portable and inexpensive. Unlike stationary, expensive ATS systems, the AFD described here can be used in multiple types of freshwater areas from small neighborhood ponds to larger lakes. The device also requires specific algae to be inserted and locked into a clear, closed device with an interior filter rather than populating the filter with algae from the incoming water in an open system such as ATS.

If this algal filtration method were utilized in a lake, multiple devices could be deployed simultaneously to decrease the time needed to filter all of the water through the device(s) one time. To determine the time and number of devices needed for filtration, a pair of relationships must be established. In the equation below, $t$ is time (day), $V$ is volume $\left(\mathrm{m}^{3}\right)$, and $F$ is the flow rate integrated from time 0 to time $t\left(\mathrm{~m}^{3}\right)$

$$
\begin{aligned}
& t\left(1-\ln F-\frac{V}{F}\right) \ln V \\
& =\frac{V}{F}\left(\frac{V}{F} \ln V-t\right)\left(\ln V-\ln F+V\left(\ln V-\ln F+\frac{F t}{V}\right)\right)+\frac{V}{F} \ln V-t .
\end{aligned}
$$

The smallest ATS available covers $1012 \mathrm{~m}^{2}$ of land (roughly 2.5 acres) versus one unit of the algal filtration system, which covers $4.3 \times 10^{-2} \mathrm{~m}^{2}$ of land (roughly $1.1 \times 10^{-3}$ acres). Thus the three devices needed to clean the $100,000 \mathrm{~m}^{3}$ volume of lake water would only occupy $1.3 \times 10^{-1} \mathrm{~m}^{2}$ of land (roughly $3.3 \times 10^{-3}$ 
acres). Even though more experimental devices would be needed to achieve the same flow as the ATS, the algal filtration system would require much less space to achieve the same filtration rate under ideal conditions. One algal filtration device costs roughly $\$ 350$ to build, including the PVC pipe and connectors, fittings, tubing, filters, recirculating pump, and algae. The three devices needed to clean the $100,000-\mathrm{m}^{3}$ lake would cost approximately $\$ 1050$. Even if multiple devices are needed for a larger lake, the device's small size and utilization of commonly available construction materials offer an economical and attainable solution.

Overall, the $S$. grevilleana paired with the algal filtration device reduced $E$. coli levels and lowered nitrate and phosphate levels, effectively improving the water quality in the freshwater lake water samples and showing the feasibility of effective utilization of the algal filtration unit for use in the field improving the water quality of freshwater lakes. Future testing of the efficacy of the algal filtration devise should include various water source additional algal species and a range of algal biomass levels. The circulating pump could be solar powered to make the device self-sufficient, portable and sustainable. Experimentation could then take place in the field setting at a freshwater lake to investigate the potential for generating potable water using this algal filtration method.

The algal filtration device is sustainable, economical, and portable, which makes the device suitable to improve water quality in freshwater lakes of different sizes and in multiple areas. $S$. grevilleana was selected as it is native to Georgia lakes. S. grevilleana has also been shown to increase dissolved oxygen concentrations [30] [31]. S. grevilleana is found in freshwater lakes worldwide; however, different algae could also be tested to determine the most efficient algal species for algal filtration under region specific conditions.

Nutrient mismanagement, including excess fertilizer use, is a major threat to water quality and chemical removal of E. coli and excess nutrients from water is expensive. In addition to spiking $E$. coli levels, fertilizer pollution from runoff can damage lake ecosystems and food chains, and impairs water quality. Utilizing algal biological conversion to reduce $E$. coli and pollution from runoff could provide a sustainable method for improving our increasingly scarce and impaired water resources.

\section{Acknowledgements}

This research was supported by an Action for Nature International Eco Hero Award. Equipment and supplies were donated by the Hach Company, 3M, and Adopt-a-Stream. Support was also provided by the science department at Johns Creek High School in Johns Creek, Georgia, USA, and by Dr. Alan P. Covich of the University of Georgia's Odum School of Ecology and Dr. Todd C. Rasmussen of the University of Georgia's Warnell School of Forestry and Natural Resources.

\section{References}

[1] Oki, T. (2006) Global Hydrological Cycles and World Water Resources. Science, 313, 1068-1072. https://doi.org/10.1126/science.1128845 
[2] Bauer, L. and Alm, E. (2012) Escherichia Coli Toxin and Attachment Genes in Sand at Great Lakes Recreational Beaches. Journal of Great Lakes Research, 38, 129-133. https://doi.org/10.1016/j.jglr.2011.10.004

[3] Barnard, M.A. (2014) Algal System for Improving Water Quality, in Google Patents, Barnard, M.A., Ed., USPTO, United States.

[4] Barnard, M.A. (2014) Algal System for Improving Water Quality, in Google Patents, Barnard, M.A., Ed., C.P.A.T. Office, Canada.

[5] Ansari, N.A., Hemavani, C. and Thippeswamy, B. (2012) Evaluation of Antimicrobial Property of Spirogyra Species. International Multidisciplinary Research Journal, 2, 13-15.

[6] Shalaby, E. (2011) Algae as Promising Organisms for Environment and Health. Plant Signaling \& Behavior, 6, 1338-1350. https://doi.org/10.4161/psb.6.9.16779

[7] Adrien, R. (2011) Characterization of Freshwater Algae from JKUAT and Evaluation of Its Bioethanol and Biodiesel Potential. Jomo Kenyatta University of Agriculture and Technology, Juja.

[8] Shalaby, E. (2014) Algae as Promising Organisms for Environment and Health. Plant Signaling \& Behavior, 6, 1338-1350. https://doi.org/10.4161/psb.6.9.16779

[9] Prakash, J.W., Antonisamy, J.M. and Jeeva, S. (2011) Antimicrobial Activity of Certain Fresh Water Microalgae from Thamirabarani River, Tamil Nadu, South India. Asian Pacific Journal of Tropical Biomedicine, 1, S170-S173. https://doi.org/10.1016/S2221-1691(11)60149-4

[10] Ivanova, A., et al. (2011) Compounds with Antibacterial Activity from the Freshwater Alga Spirogyra crassa (L.) Kutz. Genetics and Plant Physiology, 1, 1-2.

[11] Mehta, S.K. and Gaur, J.P. (2005) Use of Algae for Removing Heavy Metal Ions from Wastewater: Progress and Prospects. Critical Reviews in Biotechnology, 25, 113-152. https://doi.org/10.1080/07388550500248571

[12] Rosen, B.H., et al. (2000) Waterborne Pathogens in Agricultural Watersheds. US Department of Agriculture, Hawesville.

[13] Ansa, E.D.O., Lubberding, H.J. and Gijzen, H.J. (2008) Fecal Coliform Removal in Algal-Based Domestic Wastewater Treatment Systems. Conference Proceedings from the 2008 UCOWR Conference, Southern Illinois University Carbondale.

[14] Bouteleux, C., et al. (2005) Escherichia Coli Behavior in the Presence of Organic Matter Released by Algae Exposed to Water Treatment Chemicals. Applied and Environmental Microbiology, 71, 734-740. https://doi.org/10.1128/AEM.71.2.734-740.2005

[15] Byappanahalli, M.N., et al. (2003) Growth and Survival of Escherichia coli and Enterococci Populations in the Macro-Alga Cladophora (Chlorophyta). FEMS Microbiology Ecology, 46, 203-211. https://doi.org/10.1016/S0168-6496(03)00214-9

[16] Stedtfeld, R.D., et al. (2006) Detection and Occurrence of Indicator Organisms and Pathogens. Water Environment Research, 78, 1054-1077. https://doi.org/10.2175/106143006X119152

[17] Rose, J.B., et al. (2001) Climate Variability and Change in the United States: Potential Impacts on Water and Foodborne Diseases Caused by Microbiologic Agents. Environmental Health Perspectives, 109, 211. https://doi.org/10.2307/3435011

[18] Twichell, S., et al. (2002) Nutrient and Freshwater Inputs from Sewage Effluent Discharge Alter Benthic Algal and Infaunal Communities in a Tidal Salt Marsh Creek. Biological Bulletin, 203, 256-258.

[19] Paerl, H.W. (1997) Coastal Eutrophication and Harmful Algal Blooms: Importance of Atmospheric Deposition and Groundwater as "New" Nitrogen and Other $\mathrm{Nu}$ - 
trient Sources. Limnology and Oceanography, 42, 1154-1165.

https://doi.org/10.4319/lo.1997.42.5_part_2.1154

[20] Cook, M.G., et al. (1994) Soils and Water Quality. AG (North Carolina Agricultural Extension Service), Morganton.

[21] Herdendorf, C.E. (1983) Lake Erie Water Quality 1970-1982. National Service Center for Environmental Publications, New York.

[22] Olapade, O.A., et al. (2006) Microbial Communities and Fecal Indicator Bacteria Associated with Cladophora Mats on Beach Sites along Lake Michigan Shores. Applied and Environmental Microbiology, 72, 932-1938. https://doi.org/10.1128/aem.72.3.1932-1938.2006

[23] Dolan, D.M. and McGunagle, K.P. (2005) Lake Erie Total Phosphorus Loading Analysis and Update: 1996-2002. Journal of Great Lakes Research, 31, 11-22.

[24] Adey, W.H., Kangas, P.C. and Mulbry, W. (2011) Algal Turf Scrubbing: Cleaning Surface Waters with Solar Energy while Producing a Biofuel. BioScience, 61, 434441. https://doi.org/10.1525/bio.2011.61.6.5

[25] Fenton, O. (2012) Agricultural Nutrient Surpluses as Potential Input Sources to Grow Third Generation Biomass (Microalgae): A Review. Algal Research, 1, 49-56.

[26] Company, H. (1997) DR/890 Colorimeter Procedures Manual.

[27] Service, U.P.H. (1962) Drinking Water Standards. Public Health Service Publications, Washington DC.

[28] Patel, V.K., et al. (2017) Exploring Microalgae Consortia for Biomass Production: A Synthetic Ecological Engineering Approach towards Sustainable Production of Biofuel Feedstock. Algal Biofuels, 109-126.

[29] Christenson, L. and Sims, R. (2011) Production and Harvesting of Microalgae for Wastewater Treatment, Biofuels, and Bioproducts. Biotechnology Advances, 29, 686-702. https://doi.org/10.1016/j.biotechadv.2011.05.015

[30] Schumacher, G.J. (1956) A Qualitative and Quantitative Study of the Plankton Algae in Southwestern Georgia. American Midland Naturalist, 56, 88-115.

[31] Bachoon, D.S., et al. (2009) Assessment of Faecal Pollution and Relative Algal Abundances in Lakes Oconee and Sinclair, Georgia, USA. Research \& Management, 14, 139-149.

Scientific Research Publishing

\section{Submit or recommend next manuscript to SCIRP and we will provide best service for you:}

Accepting pre-submission inquiries through Email, Facebook, LinkedIn, Twitter, etc. A wide selection of journals (inclusive of 9 subjects, more than 200 journals)

Providing 24-hour high-quality service

User-friendly online submission system

Fair and swift peer-review system

Efficient typesetting and proofreading procedure

Display of the result of downloads and visits, as well as the number of cited articles

Maximum dissemination of your research work

Submit your manuscript at: http://papersubmission.scirp.org/

Or contact ajps@scirp.org 